Jožica Pika

Grame

Zavod RS za

šolstvo

\title{
Državljanska kultura v poklicnih šolah
}

\section{Usposabljanje učiteljev za aktiven pristop pri pouku državljanske kulture}

$P_{r}$ ske kultrie v poklichih šolah se zavedamo številnih dilem na tem področju. Prek sistema študijskih skupin usposabljamo učitelje za aktiven pristop pri pouku državljanske kulture. Tako ure ne bodo temeljile samo na posredovanju dejstev, temveč na razmisleku

Cilj državljanske vzgoje je razvijanje

sposobnosti za javno delovanje.

o lastnem izkustvu dijakov in njegovem bogatenju. Pomembne oblike dela so torej tiste, ki spodbujajo pozitivne odnose med učiteljem in dija$\mathrm{ki}$, razvijajo sodelovanje, samostojnost, spretnost odločanja, razumevanje, spoznavanje in pozitivno vplivajo na samopodobo (metoda sodelovalnega učenja, projektno delo, igranje vlog, socialne igre, obiski različnih institucij, organiziranje različnih srečanj, izdajanje šolskega časopisa ...).

$\mathrm{S}$ tem ponudimo mladim možnost, da ob številnih civilizacijskih zadregah sodobnega sveta aktivno posegajo $\mathrm{v}$ dogajanje in svobodno izražajo svoje ideje, stališča. Predvsem pa pri tem prihajajo do lastnih spoznanj. Cilj ni teorija, temveč sposobnost za delovanje in pripravljenost za državljansko vlogo. Pri tako zastavljenem pouku se pokažejo vse tri razsežnosti pouka: intelektualna, socialna in čustvena. tako na pridobivanju znanja, ki naj bi mla-

dostniku omogočilo čim boljše razumevanje sebe in družbe, katere del je. 